\title{
Association of endometritis and ovarian follicular cyst with mastitis in dairy cows
}

\author{
Fika Yuliza PURBA ${ }^{1,2)}$, Naoki SUZUKI ${ }^{1)}$ and Naoki ISOBE ${ }^{3) *}$ \\ 1)Graduate School of Biosphere Science, Hiroshima University, Higashi-Hiroshima, Hiroshima 739-8528, Japan \\ ${ }^{2)}$ Veterinary Medicine Study Program, Faculty of Medicine, Hasanuddin University, Makassar 90245, Indonesia \\ ${ }^{3)}$ Graduate School of Integrated Sciences for Life, Hiroshima University, Higashi-Hiroshima, Hiroshima \\ 739-8528, Japan
}

J. Vet. Med. Sci.

83(2): 338-343, 2021

doi: 10.1292/jvms.20-0652

Received: 15 November 2020 Accepted: 7 December 2020 Advanced Epub:

18 December 2020
ABSTRACT. The occurrence of multiple metabolic and inflammatory diseases in dairy cows is higher during the periparturient period, which may be triggered by bacterial components, but not a viable bacterium. This study aimed to determine the association of endometritis and ovarian follicular cyst (OFC) with mastitis in dairy cows. Ninety-eight Holstein dairy cows were clinically examined for endometritis and OFC approximately 30-50 days after calving. Blood and milk samples were collected for the determination of milk somatic cell count (SCC); milk interleukin$1 \beta$ (IL-1 $\beta$ ), tumor necrosis factor-a (TNFa), and interleukin-8 (IL-8) concentrations; and plasma haptoglobin ( $\mathrm{Hp}$ ) and lipopolysaccharide-binding protein (LBP) concentrations. Of the 98 dairy cows included in this study, 12 were diagnosed with endometritis and 37 cows were identified as OFC-positive, whereas the remaining 49 cows were healthy (without endometritis or OFC). The average and maximum SCCs and plasma Hp and LBP concentrations were not significantly different between the healthy cows and those with endometritis or OFC. However, when the maximum SCC was classified as $<300,300-1,000$, or $>1,000 \times 10^{3}$ cells $/ \mathrm{ml}$, the percentage of cows with the maximum SCC $<300 \times 10^{3}$ cells $/ \mathrm{ml}$ was significantly lower in the endometritis and OFCpositive groups than in the healthy group. These results suggested that cows with endometritis and OFC during the postpartum period exhibit high SCC, indicating that some bacterial components can be transferred between organs.

KEY WORDS: endometritis, lipopolysaccharide, mastitis, ovarian follicular cyst

Reproduction is the key process supporting dairy production, as poor reproductive performance can lead to involuntary culling of dairy cows, resulting in substantial economic losses [16]. Low reproductive performance appears to be influenced by high disease incidence during the transition or periparturient period, which encompasses the period from 3 weeks prepartum to 3 weeks postpartum [13]. The transition period is considered to be the most critical period for dairy cows, as the endocrine and physiological changes occurring during parturition negatively affect the immune function [11].

Bacterial occurrence is common in the uterus of dairy cows during the early postpartum period; however, most cows eliminate these bacteria within the first 2 weeks after calving [15]. Persistent bacterial colonization in the uterus can lead to subsequent infections, with puerperal metritis, clinical endometritis, pyometra, and subclinical endometritis being the most common infections [6]. Clinical endometritis is the most common periparturient disease, accounting for approximately $15 \%$ of the total disease prevalence [26]. This disease is characterized by the presence of purulent ( $>50 \%$ pus) or mucopurulent (50\% pus and 50\% mucus) uterine exudate in the vagina, 21 days or more after parturition, and it is not accompanied by any systemic signs [15].

Trueperella pyogenes, Escherichia coli, Fusobacterium necrophorum, and Prevotella melaninogenica are the most frequently isolated bacteria from bovine uterine lumen and endometritis-affected cows and are often associated with endometrial lesions [32]. In addition to bacteria, the vaginal discharge of cows was reported to contain high concentrations of lipopolysaccharides (LPS), which are membrane components of Gram-negative bacteria, 1-2 days after calving [5]. LPS derived from uterine inflammation, both during natural and induced endometritis, can increase the LPS concentration in the peripheral blood, leading to systemic inflammation [9]. Furthermore, LPS have been reported to translocate from the uterus to the mammary gland via the bloodstream [23, 24].

Several studies have reported the relationship between mastitis and reproductive performance in dairy cows, including longer intervals to conception, higher probability of embryonic loss and abortion, and failure to conceive after the first service [27, 28, 34]. However, little is known about the relationship between mastitis and other reproductive diseases. In a previous study, subclinical endometritis was found to be directly associated with subclinical mastitis in dairy cows both 4 and 8 weeks postpartum. This 
association might be attributed to the translocation of bacteria or bacterial products [1]. Furthermore, the incidence of mastitis was reported to be associated with follicular dynamics in the ovary [25, 34], but not with the presence of ovarian follicular cyst (OFC).

Abnormal reproductive occurrences during the periparturient period have also been associated with higher incidence of ovarian cysts $[3,7]$. An OFC develops when one or more follicles that have failed to ovulate continue to grow and maintain steroidogenesis instead of regressing [14]. OFC may be defined as follicles with a diameter of at least $2 \mathrm{~cm}$, present in one or both ovaries in the absence of the corpus luteum, and interfere with normal ovarian cyclicity [31].

The development of OFC in bovines has been linked to altered hypothalamus-pituitary function. Cysts can form if the preovulatory luteinizing hormone (LH) surge is absent or of insufficient magnitude, or if it does not occur at the appropriate time during dominant follicle maturation $[8,22]$. LPS is known to be involved in the pathology of cystic follicle disease [29]. LPS infusion in the uterine lumen weakened the pre-ovulatory LH surge in heifers, leading to failed ovulation and formation of OFC [21]. Furthermore, the accumulation of LPS derived from Gram-negative bacteria has been reported in the follicular fluid of animals with metritis [12]. Thus, translocation of LPS from the uterus and mammary gland to the follicle may lead to the formation of OFC due to the disruption of ovarian function [4, 17, 33].

Based on the evidence that LPS can translocate from the mammary gland and other organs via circulation, we hypothesized that LPS can also translocate from the uterus to the mammary gland and from the mammary gland to the follicle. Therefore, we aimed to determine the association of endometritis and OFC with high somatic cell count (SCC) in dairy cows.

\section{MATERIALS AND METHODS}

\section{Animals}

A total of 98 Holstein-Friesian dairy cows (bodyweight 600-750 kg, parity 1-6, 30-50 days postpartum) were included in this study. The experimental cows were housed at the experimental farm of Hiroshima University $(\mathrm{n}=78)$ or at private farms around the Hiroshima Prefecture $(n=20)$, in Japan. Cows were milked twice per day at 08:00 and 15:00. This study was approved and conducted in accordance with the guidelines of the Hiroshima University Animal Research Committee.

\section{Identification of cows with endometritis and OFC}

Endometritis and OFC were clinically evaluated. Endometritis was diagnosed by inspecting the cows for vulval discharge around the perineum and tail and vaginal inspection using a sterilized stainless-steel speculum $(40 \times 5 \mathrm{~cm}), 30-50$ days after calving. Visible discharge in the vagina was classified on a scale of 0 to 3 , following the criteria set by Williams et al. [32]. A score of 0 indicated clear or translucent mucus as in healthy cows, a score of 1 indicated mucus containing flecks of white or off-white pus, a score of 2 indicated discharge containing less than 50\% white or off-white mucopurulent material, and a score of 3 was assigned if the discharge was sanguineous or contained more than $50 \%$ white or yellow pus.

OFC were identified by rectal palpation of the cows with a gloved hand. Cows with ovarian follicles greater than $2 \mathrm{~cm}$ in diameter and without the luteal structure were identified as OFC-positive [31].

\section{Blood and milk sampling}

Blood and milk samples were collected once from each cow during the clinical examination. Blood (5 ml) was collected from the coccygeal vein into heparin-containing vacuum tubes. Then, blood samples were centrifuged at $1,900 \times g$ for $10 \mathrm{~min}$ at $4^{\circ} \mathrm{C}$, and plasma was stored at $-20^{\circ} \mathrm{C}$ for enzyme immunoassay. Milk samples were collected aseptically from the active quarters of the mammary gland by hand-milking. Milk SCC was determined using DeLaval cell counter (DeLaval International AB, Tumba, Sweden). Milk samples were then centrifuged at $1,900 \times g$ for 5 min at $4^{\circ} \mathrm{C}$. Milk fat was discarded, and skim milk was stored at $-20^{\circ} \mathrm{C}$ for enzyme immunoassay.

\section{Enzyme immunoassay}

Competitive enzyme immunoassays were used to determine interleukin-1 $\beta$ (IL-1 $\beta$ ), tumor necrosis factor- $\alpha$ (TNF $\alpha$ ), and interleukin-8 (IL-8) concentrations in milk, as previously described [18, 23].

Haptoglobin (Hp) and lipopolysaccharide-binding protein (LBP) concentrations in the plasma were determined using the sandwich enzyme immunoassay. Goat anti-bovine Hp IgG (GeneTex, CA, USA; 16 ng/ml) and rabbit anti-bovine Hp IgG (20 ng/ml) were used as capture and detection antibodies, respectively. Horseradish peroxidase-labeled anti-rabbit IgG was used to produce an enzymatic reaction. The LBP concentration was measured using a streptavidin-biotin detection system. Mouse anti-human LBP antibody (Hycult Biotech Inc., Wayne, PA, USA, $50 \mathrm{ng} / \mathrm{ml}$ ) and biotinylated rabbit anti-bovine LBP antibody (Cloud Clone Corp., Katy, TX, USA, 50 $\mathrm{ng} / \mathrm{ml}$ ) were used as capture and detection antibodies, respectively. Streptavidin-HRP (R\&D Systems Inc., Minneapolis, MN, USA) was used to bind biotin and produce the enzymatic activity required for substrate detection.

Samples were diluted 1,000 times for IL- $1 \beta$ and TNF $\alpha, 50$ times for IL-8 and LBP, and 30 times for Hp determination and optical density was measured using a microplate reader (Multiskan FC Microplate type 357, Thermo Fisher Scientific Co., Ltd., Tokyo, Japan).

\section{Statistical analyses}

Statistical analyses were performed using SAS software (version 9.4, SAS Institute Inc., Cary, NC, USA). One-way ANOVA followed by Tukey's test was used to compare milk SCC (average and maximum values); milk IL-1 $\beta$, TNF $\alpha$, and IL-8 
concentrations; and plasma Hp and LBP concentrations of cows with either endometritis or OFC and healthy cows (neither endometritis nor OFC). The chi-squared $\left(\chi^{2}\right)$ test was used to compare the number of cows (percentage) with different SCC levels (low, moderate, high) among the three tested groups (endometritis, OFC-positive, and healthy).

\section{RESULTS}

Of the 98 cows included in this study, endometritis was detected in 12 cows and 37 cows were identified as OFC-positive. The remaining cows $(n=49)$ were healthy, i.e., with neither endometritis nor OFC. The SCC parameters included average and maximum SCCs for all quarters of each cow. OFC-positive cows tended to have higher average and maximum SCCs, although no significant difference could be detected among the groups ( $P=0.311$ and $P=0.385$, respectively, Fig. $1 \mathrm{~A})$.

For a more detailed examination of the association between the health condition and SCC, the SCCs were categorized as low $\left(<300 \times 10^{3}\right.$ cells $\left./ \mathrm{ml}\right)$, moderate $\left(300-1,000 \times 10^{3}\right.$ cells $\left./ \mathrm{ml}\right)$, or high $\left(>1,000 \times 10^{3}\right.$ cells $\left./ \mathrm{ml}\right)$. The percentage of cows in each group (healthy, OFC-positive, and endometritis) was analyzed based on the SCC category. Based on the average SCC values, the percentage of cows within each SCC category (low, moderate, and high) was not remarkably different among the healthy, endometritis, and OFC-positive groups (Fig. 1B). However, based on the maximum SCC values, the percentages of cows with endometritis and OFC-positive cows were significantly higher than that of healthy cows in the low-SCC category (Fig. 1C).

The concentration of IL- $1 \beta$ in milk was significantly lower in OFC-positive cows than in healthy cows $(P=0.034$, Fig. 2A), whereas the milk TNF $\alpha$ concentration was significantly lower in OFC-positive cows than in healthy cows or those with endometritis $(P<0.001$, Fig. 2B). Furthermore, the concentration of IL-8 in milk was significantly lower in cows with endometritis than in healthy cows $(P=0.035$, Fig. $2 C$ ). Conversely, cows with endometritis presented the highest LBP and lowest Hp concentrations, whereas no

(A)

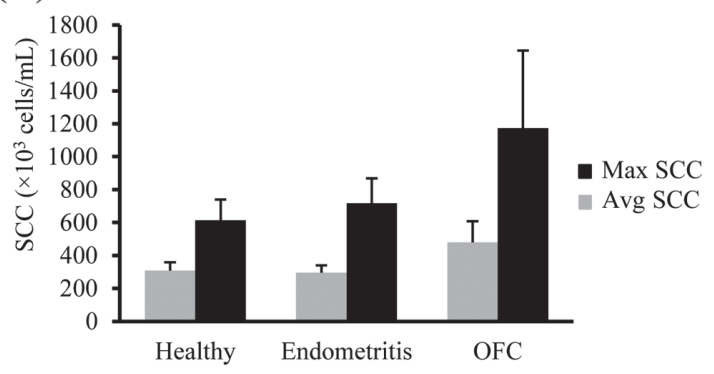

(B)

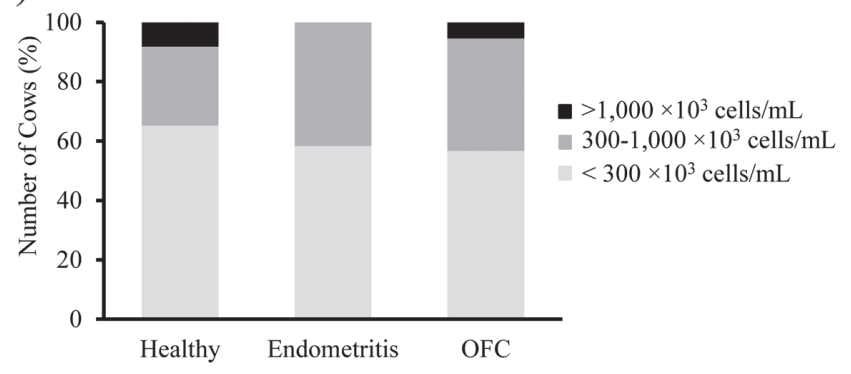

(C)

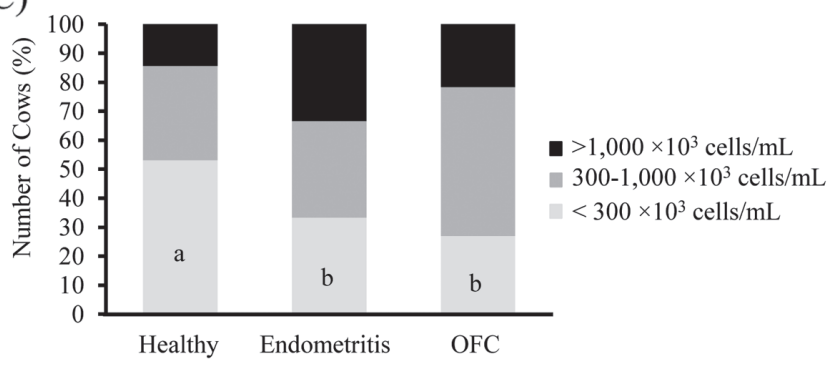

Fig. 1. Average and maximum (A) milk somatic cell count (SCC) of post-partum dairy cows and percentage of cows with different levels of average (B) and maximum (C) SCC $(<300,300-1,000,>1,000 \times$ $10^{3}$ cells $/ \mathrm{ml}$ ) in the three groups (healthy, $\mathrm{n}=49$; endometritis, $\mathrm{n}=12$; ovarian follicular cyst (OFC)-positive, $n=37)$. Values are expressed as mean \pm SEM. Values with different letters $(a, b)$ in the bars are significantly different $(P<0.05)$.
(A)

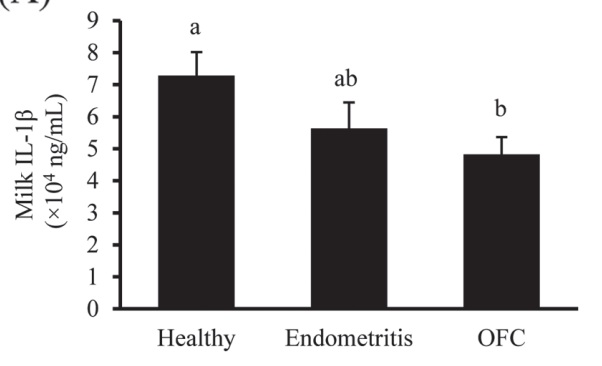

(B)

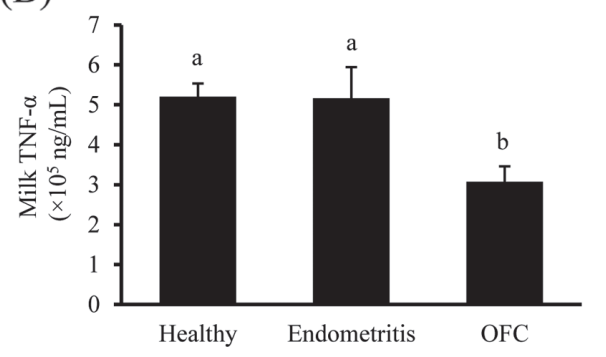

(C)

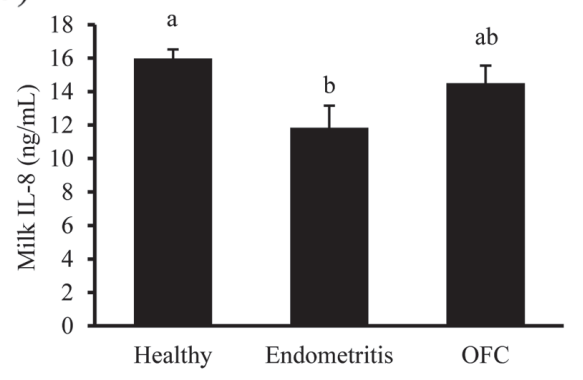

Fig. 2. Milk interleukin-1 $\beta$ (IL-1 $\beta$; A), tumor necrosis factor- $\alpha$ (TNF $\alpha$; B), and interleukin- 8 (IL-8; C) concentrations of postpartum dairy cows in the three groups (healthy, $n=49$; endometritis, $n=12$; OFC-positive, $n=37$ ). Values are expressed as mean $\pm \mathrm{SEM}$. Values with different letters $(\mathrm{a}, \mathrm{b})$ over the bars are significantly different (Fig. A and C; $P<0.05$, Fig. B; $P<0.001$ ). 
significant difference was detected among the tested groups ( $P=0.768$ and $P=0.832$, respectively, Fig. 3 ).

\section{DISCUSSION}

In the present study, 12 of the 98 cows were diagnosed with endometritis. Following the criteria proposed by Williams et al. [32] based on the characteristics of vaginal discharge, 9 cows were assigned a score of 1 and 3 cows were assigned a score of 2. Furthermore, 39 cows were identified as OFCpositive. The prevalence of clinical endometritis in Japanese dairy herds has previously been reported. Two previous studies reported a clinical endometritis prevalence of $23.6 \%$ and $32.6 \%$, within 60 days postpartum [9, 10], whereas another study reported a prevalence of $26.6 \%$ from 21 to 60 days postpartum [19]. The prevalence of endometritis in the present study was recorded as $15.4 \%$, which is lower than the previously reported values. The prevalence of OFC in dairy cows was reported to be between 5.6 and $18.8 \%$ [8]. The prevalence of OFC in the present study was $37.8 \%$ (37/98), which is higher than that reported in the previous study.

The average and maximum SCC of cows with endometritis were not significantly different from those of healthy and OFC-positive cows. However, when the maximum SCC was classified as $<300,300-1,000$, or $>1,000 \times 10^{3} \mathrm{cells} / \mathrm{ml}$, the percentage of cows with endometritis with the maximum SCC $<300 \times 10^{3}$ cells $/ \mathrm{ml}$ was significantly lower than that of healthy cows. This result indicated that cows with endometritis had higher SCCs than healthy cows. However, the percentage of cows with endometritis with average SCCs $<300 \times 10^{3} \mathrm{cell} / \mathrm{s} / \mathrm{m} l$ was not significantly different from that of healthy cows. Mastitis generally occurs in only one udder; therefore, the average SCC of the 4 udders does not reflect the occurrence of mastitis in any one udder. This explains why only the maximum SCC values in the low-SCC category were significantly different between the groups. Collectively, these results suggest a link between endometritis and mastitis; however, the causal relationship remains unknown. Purba et al. [24] reported an increase in SCC after an intrauterine infusion of LPS, indicating that LPS can translocate from the uterus to the mammary gland. However, translocation of LPS from the mammary gland to the uterus has not been reported.

Milk IL-8 concentration of cows with endometritis was significantly lower than that of healthy cows. IL- 8 is a chemokine that recruits leukocytes to the mammary gland. Numerous leukocytes are recruited to the udder in cows with endometritis. The reason for the low IL-8 concentration in the milk of cows with endometritis is not clear, although other chemokines, such as members of the $\mathrm{C}-\mathrm{C}$ motif ligand (CCL) family, may be involved.

On the other hand, there was no association observed between endometritis and OFC in this study. Several research have demonstrated the effects of uterine inflammation on ovarian function in ruminants. LPS infusion into the uterus weakened the pre-ovulatory LH surge in heifers, leading to failed ovulation and formation of OFC [21]. The accumulation of LPS derived from Gram-negative bacteria has also been found in the follicular fluid in animals with metritis [12]. Considering these previous reports, that uterine inflammation affected ovarian function, it seems that the results of this study indicate that the mammary gland is more susceptible to LPS from endometritis than the ovaries.

The average and maximum SCC values of OFC-positive cows were not significantly different from those of healthy cows. However, when the maximum SCC was classified as $<300,300-1,000$, or $>1,000 \times 10^{3}$ cells $/ \mathrm{ml}$, the percentage of OFC-positive cows with the maximum SCC $<300 \times 10^{3}$ cells $/ \mathrm{ml}$ was significantly lower than that of healthy cows. This result indicated that the milk SCC of OFC-positive cows was higher than that of healthy cows. However, the percentage of cows with average SCC $<300$ $\times 10^{3} \mathrm{cell} / \mathrm{s} / \mathrm{ml}$ was not significantly different from that of healthy cows. As stated previously, mastitis generally occurs in only one udder; therefore, the average SCC does not reflect the occurrence of mastitis. Thus, only the maximum SCC values in the low-SCC category were significantly different between the groups. LPS translocation from the uterus to the follicle has been reported earlier [17]. LPS was also reported to be involved in the pathology of cystic follicle disease [29]. However, LPS from the mammary gland or mastitis has not been reported in association with OFC, since the occurrence of OFC is mainly caused by hormonal changes. The hormonal concentration has not been evaluated in this study, thus the association between mastitis and OFC remains undetermined.

Milk concentrations of IL-1 $\beta$, IL-8, and TNF $\alpha$ of OFC-positive cows were lower than those of healthy cows. A previous study employing a model of persistent follicles revealed that IL-8 and TNF $\alpha$ levels were higher only during the initial 5 days of follicular persistence [30]. Furthermore, in another study characterizing pro-inflammatory cytokines in cows with spontaneous OFC, no difference was reported in the mRNA expression of IL-1 $\beta, T N F \alpha$, and IL- 6 between the cystic and dominant follicles, as indicated by the results of RT-PCR analyses [2]. Thus, as OFC were formed spontaneously in the present study, a possible explanation for the observed result is that OFC persisted for a long time even after the concentration of pro-inflammatory cytokines had decreased.

Plasma Hp and LBP concentrations were higher in OFC-positive cows and those with endometritis than in healthy cows, albeit the difference was not significant. Acute-phase proteins (APP), such as Hp, are produced in the liver and act as systemic markers during infection and inflammation in some organs. LBP is a soluble APP that binds to bacterial LPS to elicit an immune response 
by presenting the LPS to important cell surface pattern recognition receptors, i.e., cluster of differentiation 14 (CD14) and toll-like receptor 4 (TLR4) [20]. These observations evidence that endometritis and OFC induced no or only mild systemic inflammation in the present study.

In conclusion, although the association between mastitis and OFC could not be drawn, the results of this study suggested that cows with endometritis and OFC exhibit high SCC, indicating that some bacterial components are transferred between organs.

CONFLICT OF INTEREST STATEMENT. The authors declare that they have no conflicts of interest.

ACKNOWLEDGMENTS. This work was supported by the JSPS Grants-in-Aid for Scientific Research (18K05946, 19H0310852) conferred to Naoki Isobe. Fika Yuliza Purba would like to thank the Indonesia Endowment Fund for Education (LPDP) for financial support in the form of a Ph.D. scholarship.

\section{REFERENCES}

1. Bacha, B. and Regassa, F. G. 2010. Subclinical endometritis in Zebu x Friesian crossbred dairy cows: its risk factors, association with subclinical mastitis and effect on reproductive performance. Trop. Anim. Health Prod. 42: 397-403. [Medline] [CrossRef]

2. Baravalle, M. E., Stassi, A. F., Velázquez, M. M. L., Belotti, E. M., Rodríguez, F. M., Ortega, H. H. and Salvetti, N. R. 2015. Altered Expression of Pro-inflammatory Cytokines in Ovarian Follicles of Cows with Cystic Ovarian Disease. J. Comp. Pathol. 153: 116-130. [Medline] [CrossRef]

3. Bosu, W. T. K. and Peter, A. T. 1987. Evidence for a role of intrauterine infections in the pathogenesis of cystic ovaries in postpartum dairy cows. Theriogenology 28: 725-736. [Medline] [CrossRef]

4. Cheong, S. H., Sá Filho, O. G., Absalon-Medina, V. A., Schneider, A., Butler, W. R. and Gilbert, R. O. 2017. Uterine and systemic inflammation influences ovarian follicular function in postpartum dairy cows. PLoS One 12: e0177356. [Medline] [CrossRef]

5. Dohmen, M. J. W., Joop, K., Sturk, A., Bols, P. E. J. and Lohuis, J. A. C. M. 2000. Relationship between intra-uterine bacterial contamination, endotoxin levels and the development of endometritis in postpartum cows with dystocia or retained placenta. Theriogenology 54: 1019-1032. [Medline] [CrossRef]

6. Földi, J., Kulcsár, M., Pécsi, A., Huyghe, B., de Sa, C., Lohuis, J. A. C. M., Cox, P. and Huszenicza, G. 2006. Bacterial complications of postpartum uterine involution in cattle. Anim. Reprod. Sci. 96: 265-281. [Medline] [CrossRef]

7. Francos, G. and Mayer, E. 1988. Analysis of fertility indices of cows with extended postpartum anestrus and other reproductive disorders compared to normal cows. Theriogenology 29: 399-412. [Medline] [CrossRef]

8. Garverick, H. A. 1997. Ovarian follicular cysts in dairy cows. J. Dairy Sci. 80: 995-1004. [Medline] [CrossRef]

9. Gautam, G., Nakao, T., Koike, K., Long, S. T., Yusuf, M., Ranasinghe, R. M. S. B. K. and Hayashi, A. 2010. Spontaneous recovery or persistence of postpartum endometritis and risk factors for its persistence in Holstein cows. Theriogenology 73: 168-179. [Medline] [CrossRef]

10. Gautam, G., Nakao, T., Yusuf, M. and Koike, K. 2009. Prevalence of endometritis during the postpartum period and its impact on subsequent reproductive performance in two Japanese dairy herds. Anim. Reprod. Sci. 116: 175-187. [Medline] [CrossRef]

11. Goff, J. P. and Horst, R. L. 1997. Physiological changes at parturition and their relationship to metabolic disorders. J. Dairy Sci. 80: $1260-1268$. [Medline] [CrossRef]

12. Herath, S., Williams, E. J., Lilly, S. T., Gilbert, R. O., Dobson, H., Bryant, C. E. and Sheldon, I. M. 2007. Ovarian follicular cells have innate immune capabilities that modulate their endocrine function. Reproduction 134: 683-693. [Medline] [CrossRef]

13. Ingvartsen, K. L. and Moyes, K. 2013. Nutrition, immune function and health of dairy cattle. Animal 7 Suppl 1: 112-122. [Medline] [CrossRef]

14. Isobe, N. 2007. Follicular cysts in dairy cows. Anim. Sci. J. 78: 1-6. [CrossRef]

15. LeBlanc, S. J., Duffield, T. F., Leslie, K. E., Bateman, K. G., Keefe, G. P., Walton, J. S. and Johnson, W. H. 2002. Defining and diagnosing postpartum clinical endometritis and its impact on reproductive performance in dairy cows. J. Dairy Sci. 85: 2223-2236. [Medline] [CrossRef]

16. LeBlanc, S. J. 2008. Postpartum uterine disease and dairy herd reproductive performance: a review. Vet. J. 176: 102-114. [Medline] [CrossRef]

17. Magata, F., Ishida, Y., Miyamoto, A., Furuoka, H., Inokuma, H. and Shimizu, T. 2015. Comparison of bacterial endotoxin lipopolysaccharide concentrations in the blood, ovarian follicular fluid and uterine fluid: a clinical case of bovine metritis. J. Vet. Med. Sci. 77: 81-84. [Medline] [CrossRef]

18. Matsukawa, S., Ueno, K., Sugino, T., Yoshimura, Y. and Isobe, N. 2018. Effects of colostrum whey on immune function in the digestive tract of goats. Anim. Sci. J. 89: 1152-1160. [Medline] [CrossRef]

19. Okawa, H., Fujikura, A., Wijayagunawardane, M. M. P., Vos, P. L. A. M., Taniguchi, M. and Takagi, M. 2017. Effect of diagnosis and treatment of clinical endometritis based on vaginal discharge score grading system in postpartum Holstein cows. J. Vet. Med. Sci. 79: 1545-1551. [Medline] [CrossRef]

20. Paape, M., Mehrzad, J., Zhao, X., Detilleux, J. and Burvenich, C. 2002. Defense of the bovine mammary gland by polymorphonuclear neutrophil leukocytes. J. Mammary Gland Biol. Neoplasia 7: 109-121. [Medline] [CrossRef]

21. Peter, A. T., Bosu, W. T. and DeDecker, R. J. 1989. Suppression of preovulatory luteinizing hormone surges in heifers after intrauterine infusions of Escherichia coli endotoxin. Am. J. Vet. Res. 50: 368-373. [Medline]

22. Peter, A. T. 2004. An update on cystic ovarian degeneration in cattle. Reprod. Domest. Anim. 39: 1-7. [Medline] [CrossRef]

23. Purba, F. Y., Ueda, J., Nii, T., Yoshimura, Y. and Isobe, N. 2020. Effects of intrauterine infusion of bacterial lipopolysaccharides on the mammary gland inflammatory response in goats. Vet. Immunol. Immunopathol. 219: 109972. [Medline] [CrossRef]

24. Purba, F. Y., Nii, T., Yoshimura, Y. and Isobe, N. 2020. Translocation of intrauterine-infused bacterial lipopolysaccharides to the mammary gland in dexamethasone-treated goats. Reprod. Domest. Anim. 55: 1688-1697 [CrossRef]. [Medline]

25. Rahman, M. M., Mazzilli, M., Pennarossa, G., Brevini, T. A. L., Zecconi, A. and Gandolfi, F. 2012. Chronic mastitis is associated with altered ovarian follicle development in dairy cattle. J. Dairy Sci. 95: 1885-1893. [Medline] [CrossRef]

26. Ribeiro, E. S., Lima, F. S., Greco, L. F., Bisinotto, R. S., Monteiro, A. P. A., Favoreto, M., Ayres, H., Marsola, R. S., Martinez, N., Thatcher, W. W. and Santos, J. E. P. 2013. Prevalence of periparturient diseases and effects on fertility of seasonally calving grazing dairy cows supplemented with concentrates. J. Dairy Sci. 96: 5682-5697. [Medline] [CrossRef]

27. Santos, J. E., Cerri, R. L., Ballou, M. A., Higginbotham, G. E. and Kirk, J. H. 2004. Effect of timing of first clinical mastitis occurrence on 
lactational and reproductive performance of Holstein dairy cows. Anim. Reprod. Sci. 80: 31-45. [Medline] [CrossRef]

28. Schrick, F. N., Hockett, M. E., Saxton, A. M., Lewis, M. J., Dowlen, H. H. and Oliver, S. P. 2001. Influence of subclinical mastitis during early lactation on reproductive parameters. J. Dairy Sci. 84: 1407-1412. [Medline] [CrossRef]

29. Shimizu, T., Ishizawa, S., Magata, F., Kobayashi, M., Fricke, P. M. and Miyamoto, A. 2018. Involvement of lipopolysaccharide in ovarian cystic follicles in dairy cow: Expressions of LPS receptors and steroidogenesis-related genes in follicular cells of cystic follicles. Anim. Reprod. Sci. 195: 89-95. [Medline] [CrossRef]

30. Stassi, A. F., Baravalle, M. E., Belotti, E. M., Rey, F., Gareis, N. C., Díaz, P. U., Rodríguez, F. M., Leiva, C. J., Ortega, H. H. and Salvetti, N. R. 2017. Altered expression of cytokines IL-1 $\alpha$, IL-6, IL-8 and TNF- $\alpha$ in bovine follicular persistence. Theriogenology 97: 104-112. [Medline] [CrossRef]

31. Vanholder, T., Opsomer, G. and de Kruif, A. 2006. Aetiology and pathogenesis of cystic ovarian follicles in dairy cattle: a review. Reprod. Nutr. Dev. 46: 105-119. [Medline] [CrossRef]

32. Williams, E. J., Fischer, D. P., Pfeiffer, D. U., England, G. C. W., Noakes, D. E., Dobson, H. and Sheldon, I. M. 2005. Clinical evaluation of postpartum vaginal mucus reflects uterine bacterial infection and the immune response in cattle. Theriogenology 63: 102-117. [Medline] [CrossRef]

33. Williams, E. J., Sibley, K., Miller, A. N., Lane, E. A., Fishwick, J., Nash, D. M., Herath, S., England, G. C. W., Dobson, H. and Sheldon, I. M. 2008. The effect of Escherichia coli lipopolysaccharide and tumour necrosis factor alpha on ovarian function. Am. J. Reprod. Immunol. 60: $462-473$. [Medline] [CrossRef]

34. Wolfenson, D., Leitner, G. and Lavon, Y. 2015. The disruptive effects of mastitis on reproduction and fertility in dairy cows. Ital. J. Anim. Sci. 14: 4125. [CrossRef] 